\title{
Assessment of the Impacts of Climate Change on Hydrological Characteristics of the Mbarali River Sub Catchment Using High Resolution Climate Simulations from CORDEX Regional Climate Models
}

\author{
Edmund Mutayoba $^{1,2}$, Japhet J. Kashaigili ${ }^{3}$, Frederick C. Kahimba ${ }^{2}$, Winfred Mbungu ${ }^{2} \&$ Nyemo A. Chilagane ${ }^{3}$ \\ ${ }^{1}$ Department of Built Environmental Engineering, Mbeya University of Science and Technology, Tanzania \\ ${ }^{2}$ Department of Engineering Science and Technology Sokoine University of Agriculture, Tanzania \\ ${ }^{3}$ Department of Forest Resource Assessment and Management, Sokoine University of Agriculture, Tanzania \\ Correspondence: Edmund Mutayoba, Department of Built Environmental Engineering, Mbeya University of \\ Science and Technology, Tanzania. E-mail: Edmuta27@gmail.com
}

Received: August 4, 2018

Accepted: September 10, 2018

Online Published: September 27, 2018

doi:10.5539/apr.v10n5p61

URL: https://doi.org/10.5539/apr.v10n5p61

\begin{abstract}
This study assesses the impacts of climate change on water resources over Mbarali River sub-catchment using high resolution climate simulations from the Coordinated Regional Climate Downscaling Experiment Regional Climate Models (CORDEX_RCMs). Daily rainfall, minimum and maximum temperatures for historical climate (1971-2000) and for the future climate projection (2011-2100) under two Representative Concentration Pathways RCP 8.5 and RCP 4.5 were used as input into the Soil and Water Assessment Tool (SWAT) hydrological model to simulate stream flows and water balance components for the Mbarali River sub-catchment. The impacts of climate change on hydrological conditions over Mbarali river catchment were assessed by comparing the mean values of stream flows and water balance components during the present (2011-2040), mid (2041-2070) and end (2071-2100) centuries with their respective mean values in the baseline (1971-2000) climate condition. The results of the study indicate that, in the future, under both RCP 4.5 and RCP 8.5 emission scenarios, the four main components that determine change in catchment water balance (rainfall, ground water recharge, evaporation and surface runoff) over Mbarali river catchment are projected to increase. While the stream flows are projected to decline in the future by $13.33 \%$ under RCP 4.5 and $13.67 \%$ under RCP 8.5 emission scenarios, it is important to note that simulated surface runoff under RCP8.5 emission scenario is higher than that which is obtained under the RCP4.5 emission scenario.
\end{abstract}

Keywords: RCP, Regional climate model, General circulation models, SWAT model, hydrological water balance components.

\section{Introduction}

According to the Intergovernmental Panel on Climate Change (IPCC) assessment reports, climate change is projected to substantially reduce water availability in the watershed (IPCC, 2007, 2013 and 2014). In developing countries, Tanzania inclusive, by the year 2020, between 75 to 250 million of people are predicted to be exposed to increased water stress due to climate change (IPCC, 2007). Indeed, the only strategy to reduce impacts of climate change on water resources is to invest in the development of adaptation strategies. However, the development of water resources adaptation strategies to overcome impacts of climate change on hydrological systems is challenging (Muerth et al., 2014; Piani et al., 2010). The challenges on one hand are attributed by a lack of scientific evidence which shows the projection of how the future climate change will impact the hydrological systems. On the other hand, there are high uncertainties associated with the projections.

In Tanzania several studies that address climate change impacts on water resources have been done (e.g. Mwandosya et al., 1998). These studies have used climate simulations derived directly from the General Circulation Models (GCMs) to evaluate the impacts of climate change on water resource in Tanzania. However, the GCMs have coarse spatial resolutions (500 or $1000 \mathrm{~km}$ ) and are designed to simulate global or continent climate characteristics like global or continent temperature or rainfall amount. The coarse spatial resolutions of 
the GCMs severely limit a direct application of their output in regional and local decision making (Masson \& Knutti, 2011; Ramirez-Villegas \& Challinor, 2012). This limitation is particularly challenging in a country like Tanzania with high regional heterogeneity of its climate influenced by different topographic features (Mountain Kilimanjaro with the altitude of 5895 m, Lake Victoria in the North, Lake Nyasa and River Ruvuma in the South and Lake Tanganyika in the West). Moreover, the study by Wambura et al. (2014) underscored that GCMs climate change projections provide poor simulation of hydrological conditions at catchment scale.

Poor performance of GCMs in estimating hydrological conditions calls for evaluations of climate change impact on water resources in Tanzania. Furthermore, adaptation and mitigation policies developed based on GCMs simulation are not realistic and might pose significant challenges for anticipatory adaptation in the country. Therefore, credible evaluation of climate change impacts on water resources using high resolution downscaled GCM simulations in Tanzania is required. This study therefore evaluated the impacts of climate change on stream flows over Mbarali River sub catchment of the Rufiji basin in Tanzania using high resolution climate simulations from the Coordinated Regional Climate Downscaling Experiment Regional Climate Models (CORDEX_RCMs).

\section{Data and Methods}

\subsection{Study Area}

The Mbarali river sub-catchment has an area of $1530 \mathrm{~km}^{2}$ and is located between latitude $7{ }^{\circ} \mathrm{S}$ and $9{ }^{\circ} \mathrm{S}$ and between longitude $33.8^{\circ} \mathrm{E}$ and $35^{\circ} \mathrm{E}$ in the upper Great Ruaha sub basin of the Rufiji basin in the southern highlands of Tanzania (see Figure 1).

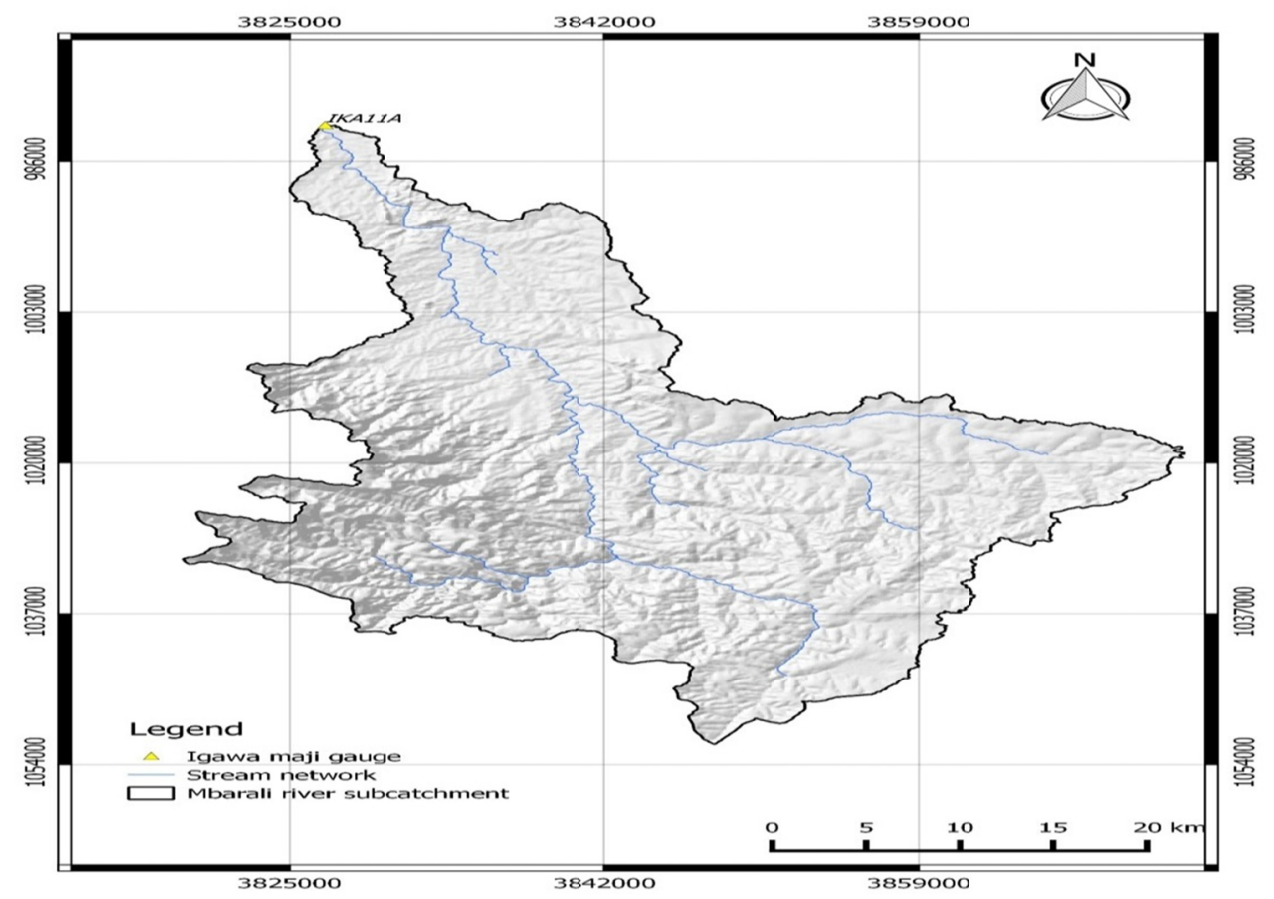

Figure 1. Location of the Study Area.

Rainfall pattern over the Mbarali river sub-catchment is mainly driven by the seasonal migration of the Inter-Tropical Convergence Zone (ITCZ). This zone moves southwards in October and reaches the southern parts of the country in January or February. Again, it reverses northwards in March, April and May. This movement makes Mbarali river sub-catchment to receive a unimodal rainfall pattern that starts in October and continues through April or May. The mean seasonal rainfall and temperature with the sub-catchment range between 450 to $650 \mathrm{~mm}$ and 25 to $30^{\circ} \mathrm{C}$ respectively. Similarly, the topography of the Mbarali sub-catchment is dominated by forest, woodland, bushland, cultivated land and grassland (see Fig.2, Land use Map). The sub-catchment is dominated by four soil types (i.e chromic Cambisols, dystric Nitosoils, dystric Regosols and Eutric Planosols) (see Fig. 2 soil map). 
Due to favorable climatic conditions and fertile soils, the Mbarali sub-catchment is important for agriculture production in the southern highlands of Tanzania. Within the sub-catchment, paddy is the main cultivated crop and the major food and cash crop. Despite the high agricultural potential of the Mbarali river sub-catchment, few studies, if any, have analyzed the impacts of climate change on water resources using high resolution climate simulations. Therefore, the study area is best placed in this kind of research study to provide reliable information about impacts of climate change on water resources that can be used to prepare adaptation strategies by policy and decision makers.

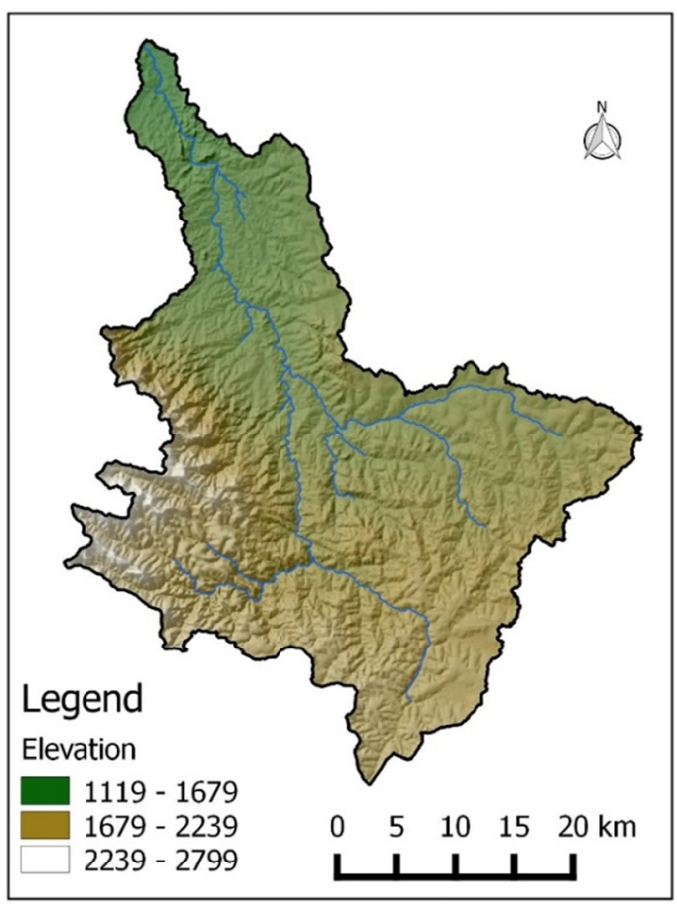

Digital Elevation Model

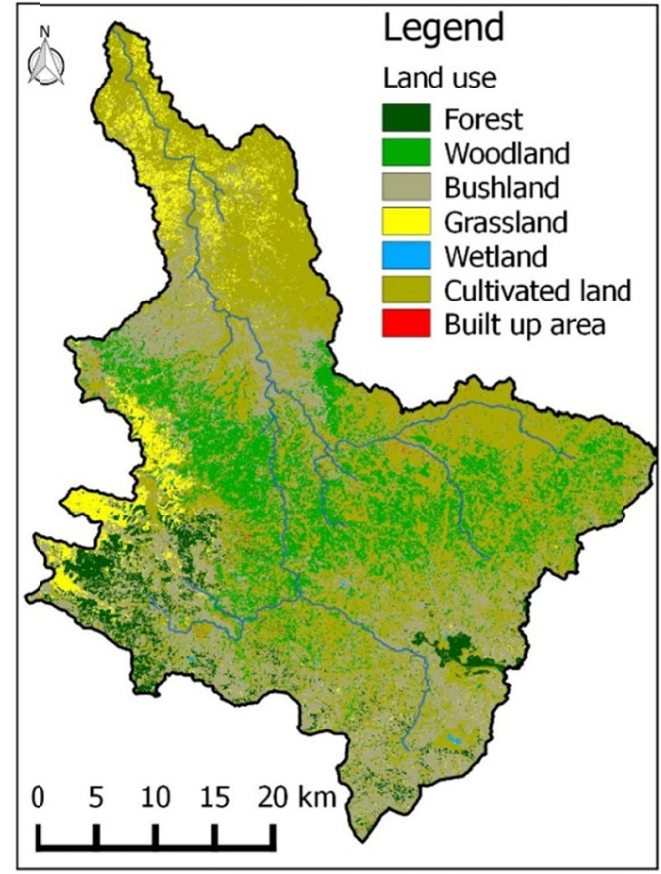

Land use map

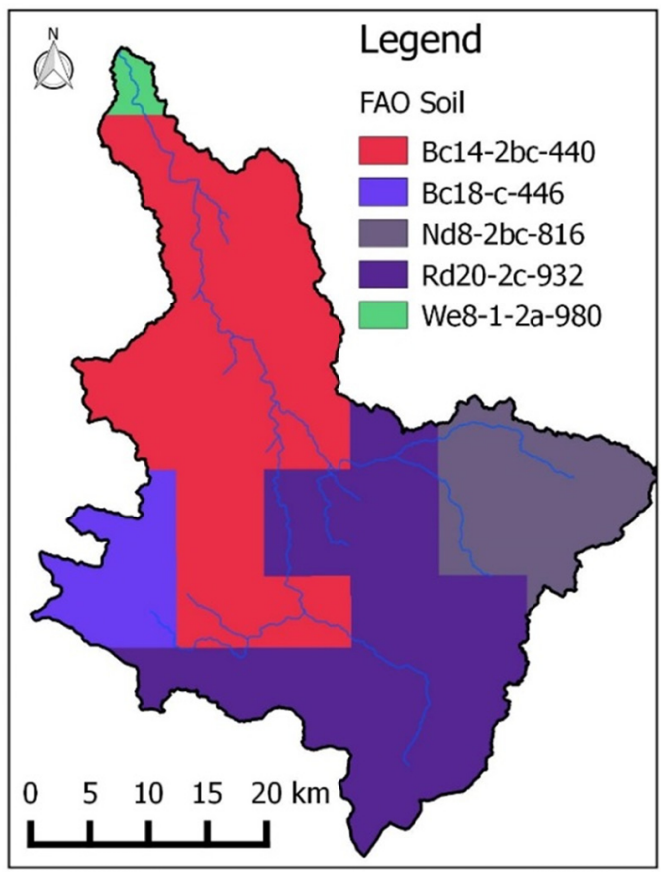

Soil map

Figure 2. Digital Elevation, Land Use and Soil Maps 


\subsection{RCM Data}

\subsubsection{Data Regional Climate Models}

Climate simulations from three high resolution regional climate models (RCMs) forced by three general circulation models (GCMs) from the Coordinated Regional Climate Downscaling Experiment (CORDEX) initiative CORDEX were used in this study. It is important to mention here that climate variables (daily rainfall, minimum and maximum temperatures) from the historical (1971-2000) and future (2011-2100) climate projections, under two Representative Concentration Pathways (RCP): RCP 4.5 and RCP 8.5 averaged over the entire sub-catchment were used to drive the SWAT hydrological model to simulate hydrological conditions over the Mbarali river sub catchment.

The RCMs and the driving GCMs used in this study are listed in Table 1. These models were chosen based on their ability to simulate the historical (1971-2000) climate condition over the southern regions of Tanzania with relatively minimum error (Luhunga et al., 2017). For a detailed description of the regional climate models and their driving general circulation models used in the CORDEX program a reader may consult Nikulin et al. (2012).

Table 1. CordexRcms and the Driving Gcms

\begin{tabular}{|c|c|c|c|c|}
\hline No & Regional climate model & Model center & Short name of RCM & Short name general circulation model \\
\hline 1 & $\begin{array}{l}\text { Rossby } \\
\text { Center Regional } \\
\text { Atmospheric } \\
\text { Model (RCA4) }\end{array}$ & $\begin{array}{l}\text { The Swedish meteorological and } \\
\text { hydrological institute (SMHI) }\end{array}$ & RCA4 & $\begin{array}{l}\text { MPI } \\
\text { CNRM-CERFACS }\end{array}$ \\
\hline 2 & $\begin{array}{l}\text { Regional } \\
\text { Atmospheric Climate Model, } \\
\text { version } 2.2 \\
(\text { RACMO2.2T) }\end{array}$ & $\begin{array}{l}\text { Koninklijk } \\
\text { Nederlands } \\
\text { Meteorologisch } \\
\text { Instituut (KNMI), } \\
\text { Netherlands }\end{array}$ & RACMO22T & ICHEC-EC-EARTH \\
\hline 3 & $\begin{array}{l}\text { The subset of High resolution } \\
\text { limited area Model (HIRLAM) } \\
\text { (HIRHAM5) }\end{array}$ & $\begin{array}{l}\text { Danmarks } \\
\text { Meteorologiske } \\
\text { Institut(DMI), } \\
\text { Danmark } \\
\end{array}$ & HIRHAM5 & ICHEC-EC-EARTH \\
\hline
\end{tabular}

\subsection{Hydrological Model and Model Input Files}

To assess future water resource availability for the Mbarali River Catchment the Soil and Water Assessment Tool (SWAT) models were used. SWAT is a semi distributed hydrological model that can quantitatively explain the processes and mechanisms that influence the behavior of the watershed (Arnold et al., 1998). This model has been used intensively by different researchers, consultants, hydrologists, policy as well as decision makers worldwide (Abbaspour et al., 2007). In this study, SWAT v10.4 was used to simulate hydrological conditions over the mbarali River sub catchment. For a detailed description of SWAT v10.4 the reader may consult Abbaspour (2009). SWAT requires DEM, soil data, and weather information to simulate hydrological conditions. Weather information required to run SWAT includes daily values of incoming solar radiation $\left(\mathrm{MJ} / \mathrm{m}^{2}\right.$-day), maximum and minimum daily air temperature $\left({ }^{\circ} \mathrm{C}\right)$ and daily rainfall $(\mathrm{mm})$. The model input files were created using several levels in SWAT. For a detailed description on how to create the model input files using SWAT reference can be made to Abbaspour(2009).

\subsection{Model Calibration and Validation}

The Soil and Water Assessment Tool (SWAT)- hydrological model is incorporated within Arc GIS version 10.4 to simulate hydrological condition as influenced by catchment characteristics. The calibration and validation of SWAT-Hydrological model to obtain reasonable estimates of model evaluation performance was performed by comparing simulated and observed stream flows data from 1KA11 Igawa maji gauge station. Daily rainfall, minimum and maximum temperatures from four CORDEX regional climate models were used to force SWAT to simulate hydrological parameters. 


\subsection{Assessment of the Impacts of Climate Change on Water Resource}

The assessment of the impacts of climate change on water resources was carried out by comparing hydrological parameters simulated in historical climate (1971-2000) against future climate (2011-2040, 2041-2070 and 2071- 2100 under two emission scenarios (RCP 4.5 and RCP 8.5). Since different CORDEX regional climate models simulate climate variables at specific location differently, this may contribute to large uncertainties in the simulated hydrological parameters. To address the issue of uncertainties introduced from the climate models, the ensemble average of four CORDEX regional climate models driven by three different GCMs was constructed. Outputs from the constructed ensemble average for RCP 4.5 and RCP 8.5 emission scenarios were used to force SWAT model to simulate the stream flows and water balance components during historical (1971-2000), and future (211-2100) climate.

\section{Results}

The results are presented in two sub sections. The first sub section presents the climate variables over the Mbarali river sub catchment as simulated by the climate models. The second sub section presents the hydrological characteristics over Mbarali river sub catchment as simulated by SWAT hydrological model.

\subsection{Climate Variables over Mbarali River Sub-catchment}

In the Mbarali river sub catchment, the RCMs from CORDEX simulate historical (1971-2000) climate variables (rainfall, minimum and maximum temperatures) differently (Figures. 3-5). All the RCMs reproduce the unimodal rainfall pattern over Mbarali river sub catchment (Figure 3). However, all RCMs simulate phase change and the magnitude of rainfall in the historical (1971-2000) climate differently. Moreover, even for the same RCM forced by different GCMs simulates the phase change and magnitude of rainfall in the historical climate differently (Figure.3). For instance RCA4 forced by different GCM (MPI) and RCA4 forced by GCM (CNRM) simulate rainfall amount of $276.13 \mathrm{~mm}$ in November and $275.66 \mathrm{~mm}$ in December respectively (Figure 3). The different RCMs forced by the same GCM simulate the phase change and magnitude of rainfall over Mbarali river sub catchment differently. Furthermore, HIRHAM5 forced by ICHEC and RACMO22T forced by ICHEC simulate rainfall amount of $269.41 \mathrm{~mm}$ in January and $222.9 \mathrm{~mm}$ in December respectively. These results indicate that, there are high uncertainties in simulating rainfall over Mbarali river sub catchment from individual model. The sources of uncertainties can be analysed and quantified when the same RCM are forced by different GCMs and different RCMs are forced by the same GCM simulate rainfall over Mbarali river sub catchment differently. However, the presented results suggest that high variability in simulated rainfall over Mbarali river sub catchment occurs when different RCMs are forced by same GCMs than when the same RCM is forced by different GCMs.

In order to reduce uncertainties associated by the individual RCMs and GCMs, the multi-model approach or ensemble average of simulated climate variables (rainfall, minimum and maximum temperatures) was created and the results can be compared with those from individual models (see Figures 3-5). Taking the ensemble average as a reference, it is found that the absolute error (biases) from the RCMs and driving GCMs contribute almost equally in simulating both rainfall and temperatures over Mbarali river sub catchment. Moreover, during the historical climate (1971-2000) the RCMs simulated the patterns and magnitude of minimum and maximum temperatures better than those of rainfall.

Figures 6-8 present the projected annual cycles of climate variables (rainfall, minimum and maximum temperatures) in the Mbarali river sub catchment as simulated by the CORDEX RCMs under two Representative Concentration Pathways (RCP8.5 and RCP 4.5). It can be seen that all the models can reproduce the annual cycles of the historical climate in the future climatic condition. However, rainfall is expected to increase in the present century (2011-2040) under both RCP 8.5 and RCP 4.5 emission scenarios. Moreover, minimum and maximum temperatures are projected to increase in the present century (2011-2040) under both RCP 8.5 and RCP 4.5 emission scenarios. 


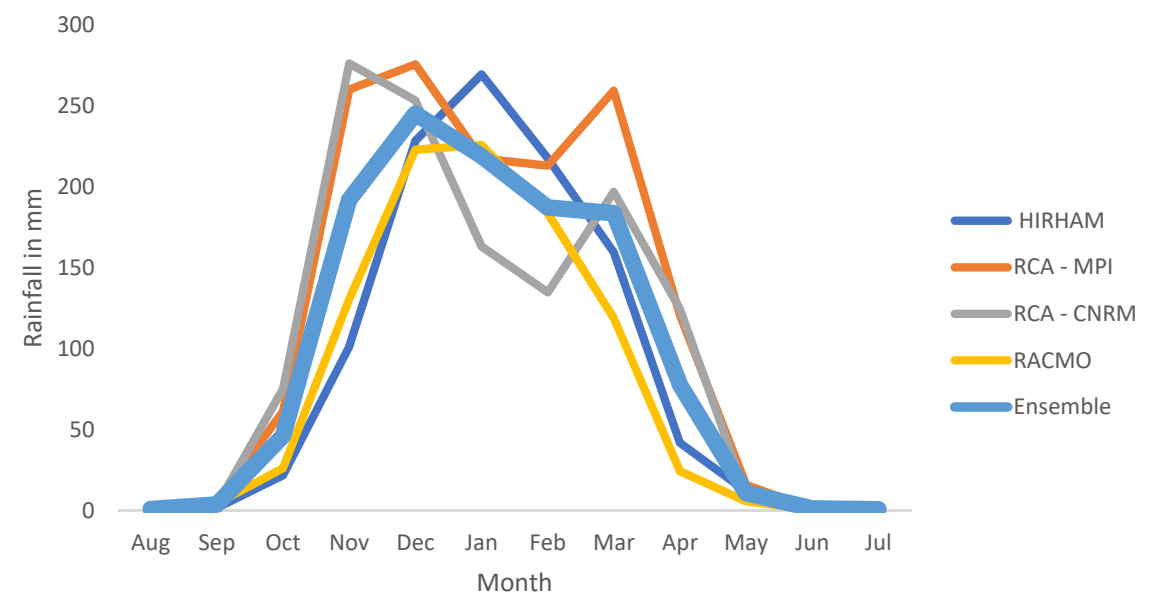

Figure 3. Simulated annual cycle of rainfall during the historical climate (1971-2000)

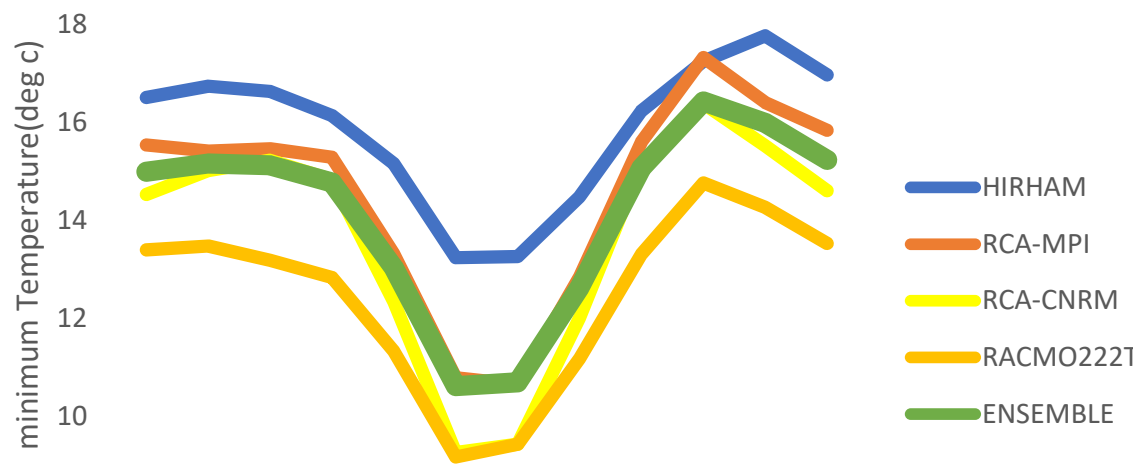

8

Jan Feb Mar Apr May Jun Jul Aug Sep Oct Nov Dec Month

Figure 4. Simulated annual cycles of minimum temperature during the historical climate (1971-2000)

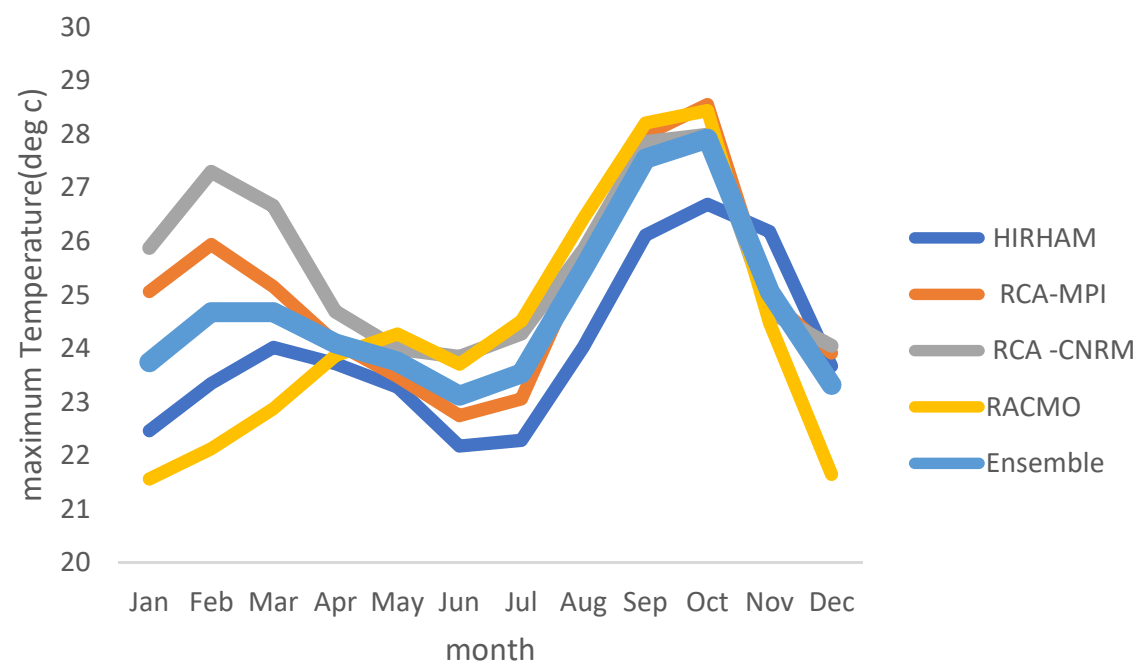

Figure 5. Simulated annual cycles of maximum temperatures during the historical climate (1971-2000) 


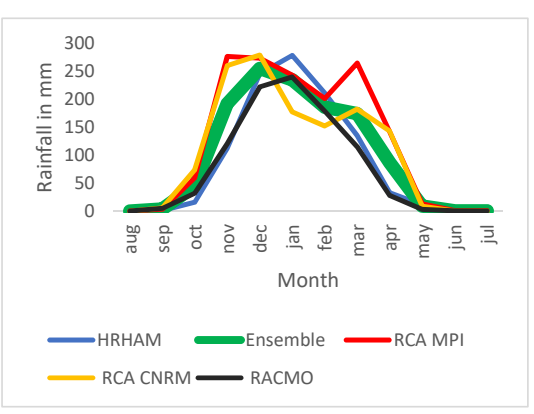

(a)

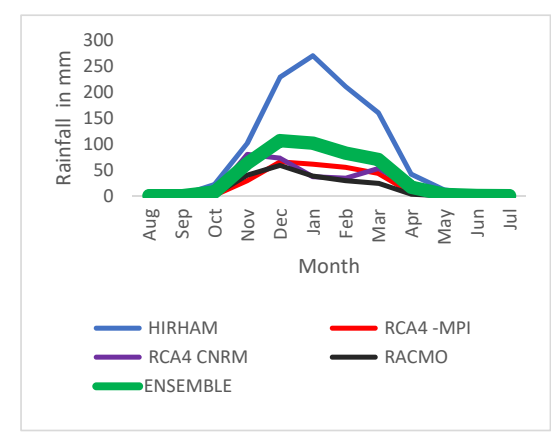

(d)

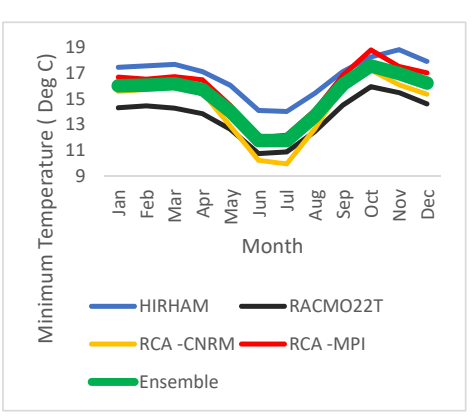

(b)

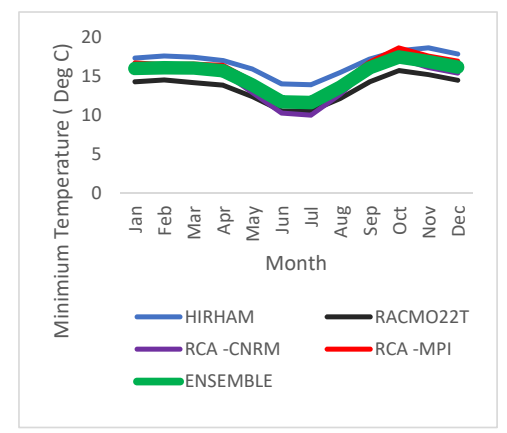

(e)

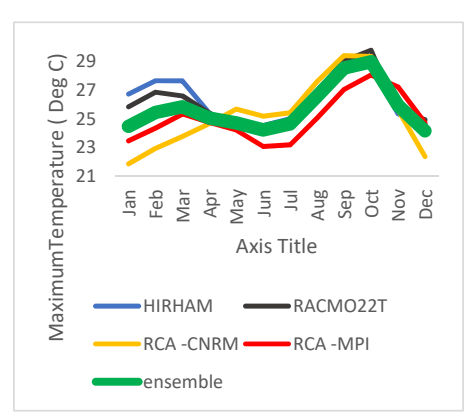

(c)

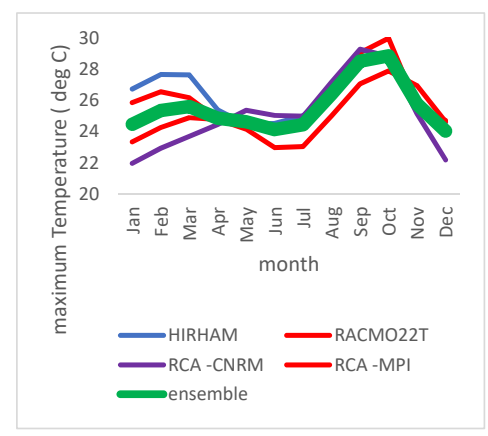

(f)

Figure 6. Simulated annual cycles of climate variables (rainfall, minimum and maximum temperatures) in the present century (2011-2040): the upper panel is for RCP 8.5 and the bottom panel is for RCP 4.5 emission scenarios

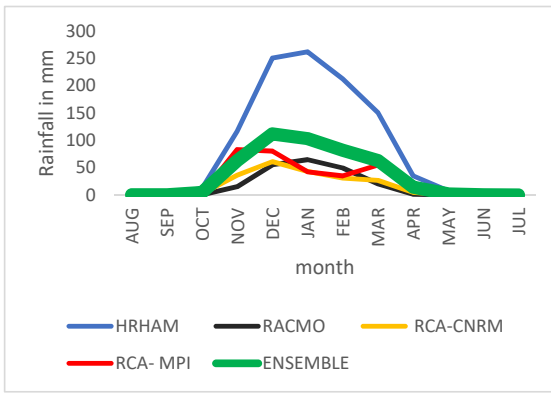

(a)

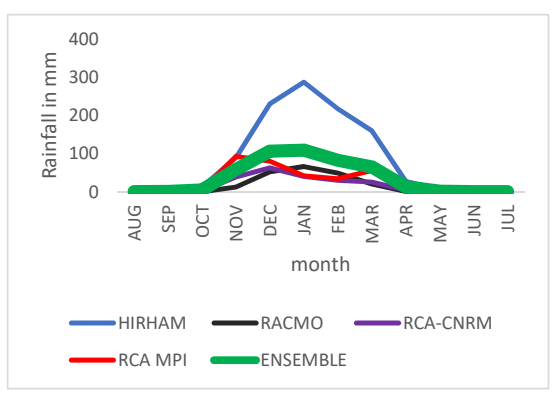

(d) mid century (2041-2070): the upper panel is for RCP 8.5 and the bottom panel is for RCP 4.5 emission scenarios

(b)
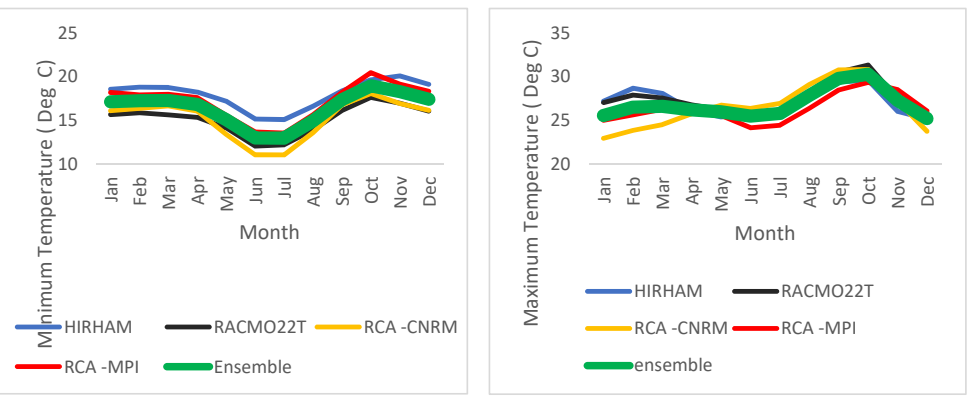

(c)

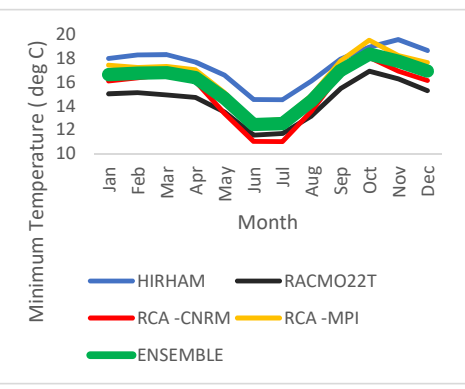

(e)

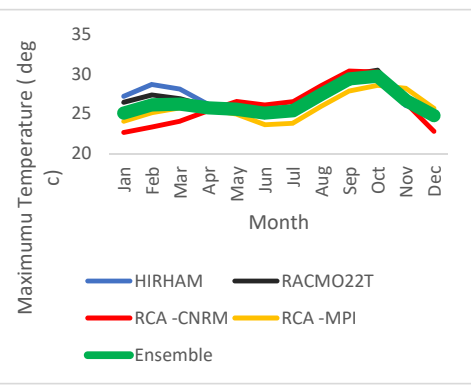

(f) 


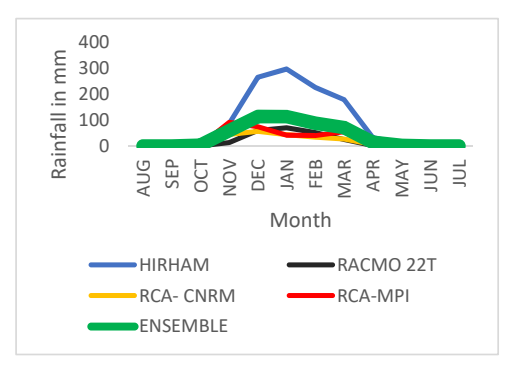

(a)

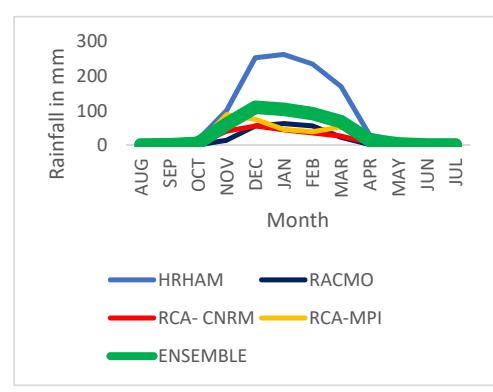

(d)

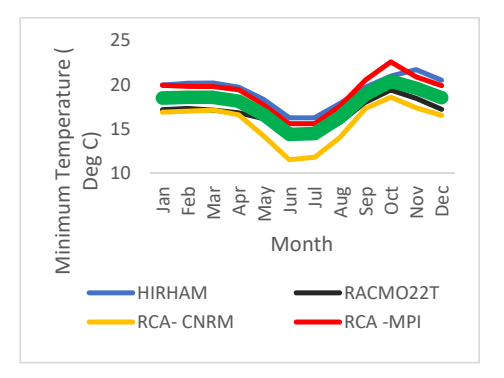

(b)

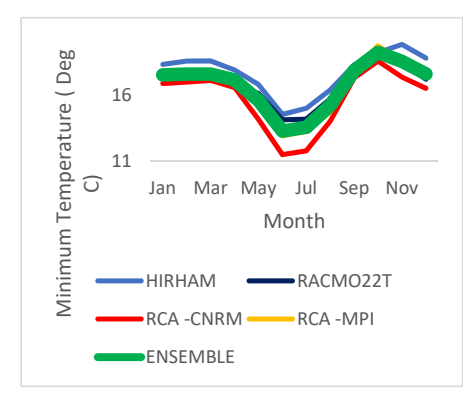

(e)

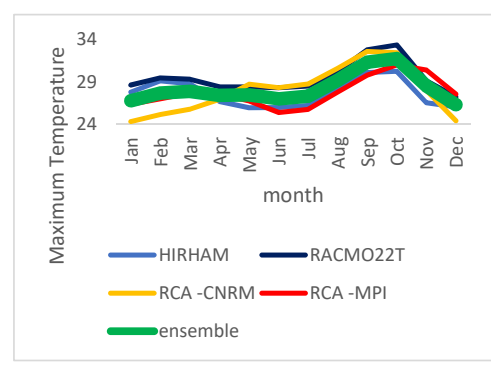

(c)

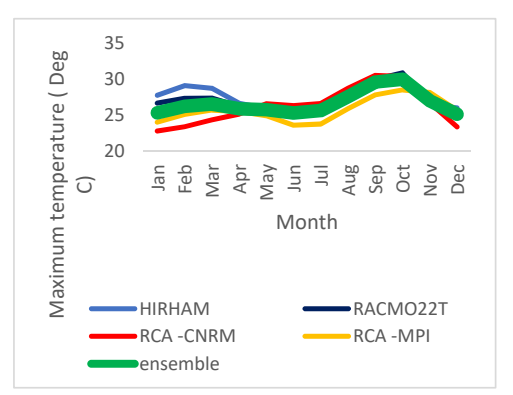

(f)

Figure 8. Simulated annual cycles of climate variables (rainfall, minimum and maximum temperatures) in the end century (2071-2100): the upper panel is for RCP 8.5 and the bottom panel is for RCP 4.5 emission scenarios

\subsection{Impacts of Climate Change on Water Resources}

\subsubsection{Impact of Climate Change on Stream Flows}

The long term means annual cycles of the simulated stream flows in baseline period (1971-2000) and future climate projections (2011-2100) under two emission scenarios (RCP 4.5 and RCP 8.5) for the Mbarali river sub-catchment are presented in Figure 9. This figure indicates two peaks of stream flows; the maximum peak is found in March and the minimum peak is found in December. The figure further shows a decline of stream flows during present, mid and end centuries from the month of March to July and from October to January. More decline of stream flows is projected to occur in the end century under both RCP 4.5 and RCP 8.5 emission scenarios. The decline of stream flows particularly during the month of October to January, affects the beginning of the hydrological year of the Mbarali river sub-catchment, which starts in November and lasts in April. The presented results agree with those obtained in the study carried by Rajabu et al. (2007) in the Upper Great Ruaha River Catchment (UGRRC). They found a decline in the annual stream flow, but with large variations along the year.

Table 2 shows the simulated annual streamflow during the baseline period (1971-2000) is $36.74 \mathrm{~m} 3 \mathrm{~s}-1$. These flows are projected to decrease during the present (2011-2040), mid (2041-2070) and end (2071-2100) centuries under both RCP 4.5 and RCP 8.5 emission scenarios. More decrease of $15.91 \%$ is projected to occur during the mid and end centuries under RCP 4.5. In the present century, more decrease of stream flows of $13.99 \%$ is projected to occur over Mbarali river sub-catchment under RCP 8.5 emission scenario.

Table 2. Mean annual stream flows for the baseline and future period as simulated by SWAT forced by ensemble RCMs under RCP 8.5 and RCP 4.5 scenario (All values are in $\mathrm{m} 3 / \mathrm{sec}$ )

\begin{tabular}{llcllllllllll}
\hline Baseline & \multicolumn{3}{c}{$\mathbf{2 0 1 1 - 2 0 4 0}$} & \multicolumn{1}{c}{$\mathbf{2 0 4 1 - 2 0 7 0}$} & \multicolumn{3}{c}{$\mathbf{2 0 7 1 - 2 1 0 0}$} \\
\hline $1971-2000$ & RCP 8.5 & $\%$ & RCP 4.5 & $\%$ & RCP 8.5 & $\%$ & RCP 4.5 & $\%$ & RCP 8.5 & $\%$ & RCP 4.5 & $\%$ \\
36.74 & 31.60 & -13.99 & 32.96 & -10.28 & 31.24 & -14.96 & 30.89 & -15.91 & 31.24 & -14.96 & 30.89 & -15.91 \\
\hline
\end{tabular}




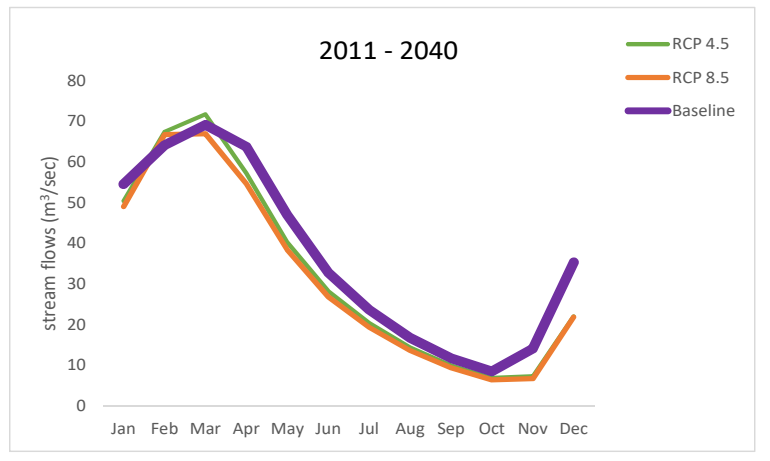

a

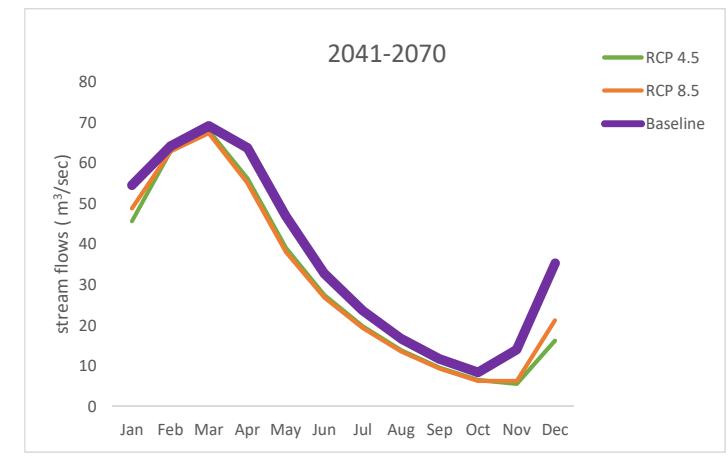

b

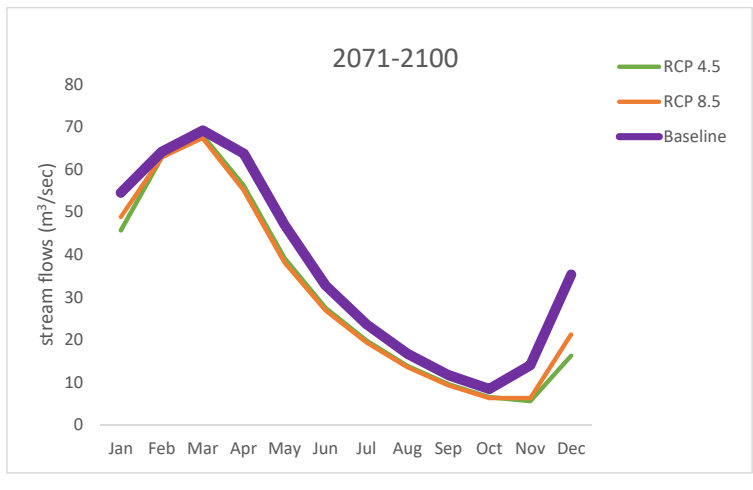

c

Figure 9. Mean monthly stream flows of RCM ensemble under RCP 4.5 and RCP 8.5 for the three future period and baseline period (1971-2000)

\subsubsection{The Impact of Climate Change on Water Balance Components}

The average annual values of water balance components for the Mbarali river sub catchment simulated by SWAT hydrological model when is forced by climate variables from different RCM-GCM combinations during the baseline (1971-2000) and future (2011-2100) climate conditions are presented in tables 3-7. During historical climate (1971-2000), the highest surface runoff of $13.95 \mathrm{~mm}$ is simulated by SWAT forced with HIRHAM-ICHEC and the lowest surface runoff of $0.15 \mathrm{~mm}$ is simulated by SWAT forced with RACMO22T-ICHEC. The uncertainties associated by different CORDEX-RCMs can be analyzed, when SWAT is forced by different RCMs, but similar GCM simulates water balance components differently. For instance, in the historical climate, SWAT simulates water yield of $719.72 \mathrm{~mm}$ and $614.99 \mathrm{~mm}$ when forced by HIRHAM-ICHEC and RACMO22T-ICHEC respectively. Moreover, SWAT forced by similar RCM, but different GCMs simulates water yield differently. For instance water yield of $825.42 \mathrm{~mm}$ and $1030.86 \mathrm{~mm}$ was simulated by SWAT driven by RCA4-CNRM and RCA4-MPI respectively. The uncertainties from the climate model may be associated with different formulation and parameterization schemes in those models. To account for uncertainties that arise from RCM-GCM combinations, the ensemble averages of four climate model members were constructed and used to force SWAT.

Table 7 shows annual average for the water balance components simulated by SWAT forced with the ensemble averages. These water balance components differ greatly from those of individual models. This is an indication of large uncertainties involved in climate change impact studies for the Mbarali river sub-catchment. However, the results from the ensemble averages that take into account the uncertainties from individual RCMs and driving GCMs are the best estimate of future climate change in the sub basin. Table 7 indicates that the ground water and water yield component are projected to decrease under RCP 8.5 during the present, mid and end centuries, while the surface runoff and evapotranspirations are projected to increase under two emission scenarios during the present, mid and end centuries. 
Table 3. Average annual basin values as simulated by SWAT Model fed with climate data from HIRHAM ICHEC for two scenarios RCP 4.5 and RCP 8.5:

Note that figures in brackets are $\%$ change

\begin{tabular}{|c|c|c|c|c|c|c|c|}
\hline \multirow[b]{2}{*}{ Units in $\mathrm{mm}$} & \multirow[b]{2}{*}{ Baseline (1971-2000) } & \multicolumn{2}{|c|}{$\begin{array}{c}\text { Present century } \\
(2011-2040)\end{array}$} & \multicolumn{2}{|c|}{$\begin{array}{l}\text { Mid century } \\
(2041-2070)\end{array}$} & \multicolumn{2}{|c|}{$\begin{array}{l}\text { End century } \\
(2071-2100)\end{array}$} \\
\hline & & $\begin{array}{c}\text { RCP } 4.5 \\
\text { (\% change) }\end{array}$ & $\begin{array}{c}\text { RCP } 8.5 \\
\text { (\% change) }\end{array}$ & $\begin{array}{c}\text { RCP } 4.5 \\
\text { (\% change) }\end{array}$ & $\begin{array}{c}\text { RCP } 8.5 \\
\text { (\% change) }\end{array}$ & $\begin{array}{c}\text { RCP } 4.5 \\
\text { (\% change) }\end{array}$ & $\begin{array}{c}\text { RCP } 8.5 \\
\text { (\% change) }\end{array}$ \\
\hline Precipitation & 1086.1 & $1073.2(-1.18)$ & $1050.0(-3.32)$ & $1040.1(-4.24)$ & $1051.7(-3.16)$ & $1084.3(-0.16)$ & $1101.7(1.43)$ \\
\hline Surface runoff $\mathrm{Q}$ & 13.95 & $18.62(33.47)$ & $15.89(13.9)$ & $16.70(19.71)$ & $17.83(27.81)$ & $21.28(52.54)$ & $35.12(58.75)$ \\
\hline Groundwater & 639.46 & $631.36(-1.26)$ & $606.68(-5.12)$ & $592.56(-7.33)$ & $598.58(-6.39)$ & $620.22(-3.00)$ & $628.19(-1.76)$ \\
\hline Total water yield & 719.72 & $715.61(-0.57)$ & $685.99(-4.68)$ & $671.70(-6.67)$ & $679.54(-5.58)$ & $706.69(-1.81)$ & $719.47(-0.03)$ \\
\hline Evaporation & 339.0 & $336.5(-0.73)$ & $337.49(-0.47)$ & $343.1(1.20)$ & $347.3(2.44)$ & $352.2(3.89)$ & $340.8(0.53)$ \\
\hline
\end{tabular}

Table 4. Average annual basin values as simulated by SWAT Model fed with climate data from RACMO22T-ICHEC for two scenarios RCP 4.5 and RCP 8.5. Note that figures in brackets are \% change

\begin{tabular}{|c|c|c|c|c|c|c|c|}
\hline \multirow[b]{2}{*}{ Units in $\mathrm{mm}$} & \multirow[b]{2}{*}{$\begin{array}{c}\text { Baseline } \\
(1971-2000)\end{array}$} & \multicolumn{2}{|c|}{$\begin{array}{l}\text { Present century } \\
(2011-2040)\end{array}$} & \multicolumn{2}{|c|}{$\begin{array}{l}\text { Mid century } \\
(2041-2070)\end{array}$} & \multicolumn{2}{|c|}{$\begin{array}{l}\text { End century } \\
(2071-2100)\end{array}$} \\
\hline & & $\begin{array}{l}\text { RCP } 4.5 \\
(\% \text { change })\end{array}$ & $\begin{array}{c}\text { RCP } 8.5 \\
\text { (\% change) }\end{array}$ & $\begin{array}{l}\text { RCP } 4.5 \\
(\% \text { change })\end{array}$ & $\begin{array}{c}\text { RCP } 8.5 \\
\text { (\% change) }\end{array}$ & $\begin{array}{c}\text { RCP } 4.5 \\
\text { (\% change) }\end{array}$ & $\begin{array}{l}\text { RCP } 8.5 \\
\text { (\% change) }\end{array}$ \\
\hline Precipitation & 955.8 & $968.2(1.29)$ & $958.5(0.28)$ & $961.5(0.59)$ & $957.0(0.12)$ & $968.3(1.30)$ & $982.6(2.80)$ \\
\hline Surface runoff & 0.15 & $0.09(-40)$ & $0.22(46.66)$ & $0.11(-26.66)$ & $0.08(-46.66)$ & $0.06(-60)$ & $0.46(86.66)$ \\
\hline Groundwater & 557.00 & $554.40(-0.46)$ & $541.63(-2.75)$ & $592.56(6.38)$ & $514.49(7.63)$ & $620.22(11.35)$ & $526.86(-5.41)$ \\
\hline Total water yield & 614.99 & $612.29(-0.43)$ & $598.47(-2.68)$ & $671.70(9.22)$ & $569.33(-7.42)$ & $706.69(14.91)$ & $583.41(-5.13)$ \\
\hline Evaporation & 319.2 & $335.5(5.10)$ & $325.9(2.09)$ & $343.1(7.48)$ & $364.9(14.31)$ & $352.2(10.33)$ & $582.40(82.45)$ \\
\hline
\end{tabular}

Table 5. Average annual basin values as simulated by SWAT Model fed with climate data from RCA - CNRM for two scenarios RCP 4.5 and RCP 8.5: Note that figures in brackets are \% change

\begin{tabular}{|c|c|c|c|c|c|c|c|}
\hline \multirow[b]{2}{*}{ Units in $\mathrm{mm}$} & \multirow[b]{2}{*}{$\begin{array}{l}\text { Baseline } \\
(1971-2000)\end{array}$} & \multicolumn{2}{|c|}{$\begin{array}{l}\text { Present century } \\
\quad(2011-2040)\end{array}$} & \multicolumn{2}{|c|}{$\begin{array}{l}\text { Mid century } \\
(2041-2070)\end{array}$} & \multicolumn{2}{|c|}{$\begin{array}{l}\text { End century } \\
(2071-2100)\end{array}$} \\
\hline & & $\begin{array}{c}\text { RCP } 4.5 \\
\text { (\% change) }\end{array}$ & $\begin{array}{c}\text { RCP } 8.5 \\
\text { (\% change) }\end{array}$ & $\begin{array}{c}\text { RCP } 4.5 \\
\text { (\% change) }\end{array}$ & $\begin{array}{c}\text { RCP } 8.5 \\
\text { (\% change) }\end{array}$ & $\begin{array}{c}\mathrm{RCP} 4.5 \\
(\% \text { change) }\end{array}$ & $\begin{array}{c}\text { RCP } 8.5 \\
\text { (\% change) }\end{array}$ \\
\hline Precipitation & 1223.7 & $1284.1(4.93)$ & $1284.1(4.93)$ & $1273.2(4.04)$ & $1273.2(4.04)$ & $1276.1(4.28)$ & $1276.1(4.28)$ \\
\hline Surface runoff & 8.63 & $12.42(43.91)$ & $12.42(43.91)$ & $14.04(62.68)$ & $14.04(62.68)$ & $11.87(37.54)$ & $11.87(37.54)$ \\
\hline Groundwater & 740.64 & $783.20(5.74)$ & $783.20(5.74)$ & $740.55(-0.01)$ & $740.55(-0.01)$ & $750.71(1.4)$ & $750.71(4.1)$ \\
\hline Total water yield & 825.42 & $875.87(6.11)$ & $875.87(6.11)$ & $831.65(0.75)$ & $831.65(0.75)$ & $840.47(1.82)$ & $840.47(1.82)$ \\
\hline Evaporation & 376.0 & $386.8(2.87)$ & $386.8(2.87)$ & $411.1(9.33)$ & $411.1(9.33)$ & $413.3(9.92)$ & $413.3(9.92)$ \\
\hline
\end{tabular}

Table 6. Average annual basin values as simulated by SWAT Model fed with climate data from RCA - MPI for two scenarios RCP 4.5 and RCP 8.5: Note that figures in brackets are \% change

\begin{tabular}{|c|c|c|c|c|c|c|c|}
\hline \multirow[b]{2}{*}{ Units in $\mathrm{mm}$} & \multirow[b]{2}{*}{$\begin{array}{c}\text { Baseline } \\
(1971-2000)\end{array}$} & \multicolumn{2}{|c|}{$\begin{array}{l}\text { Present century } \\
(2011-2040)\end{array}$} & \multicolumn{2}{|c|}{$\begin{array}{l}\text { Mid century } \\
(2041-2070)\end{array}$} & \multicolumn{2}{|c|}{$\begin{array}{l}\text { End century } \\
(2071-2100)\end{array}$} \\
\hline & & $\begin{array}{c}\mathrm{RCP} 4.5 \\
\text { (\% change) }\end{array}$ & $\begin{array}{c}\text { RCP } 8.5 \\
\text { (\% change) }\end{array}$ & $\begin{array}{c}\text { RCP } 4.5 \\
\text { (\% change) }\end{array}$ & $\begin{array}{c}\text { RCP } 8.5 \\
\text { (\% change) }\end{array}$ & $\begin{array}{c}\text { RCP } 4.5 \\
\text { (\% change) }\end{array}$ & $\begin{array}{c}\text { RCP } 8.5 \\
\text { (\% change) }\end{array}$ \\
\hline Precipitation & 1442.8 & $1446.4(0.24)$ & $1481.4(2.67)$ & $1497.8(3.81)$ & $1425.8(-1.17)$ & $1456.1(0.92)$ & $1440.7(-0.14)$ \\
\hline Surface runoff & 12.48 & $16.31(30.68)$ & $17.84(42.94)$ & $22.60(81.08)$ & $18.71(49.91)$ & $21.41(71.55)$ & $27.90(123.55)$ \\
\hline Groundwater & 924.94 & $93(0.61)$ & $783.20(-15.32)$ & $944.92(2.16)$ & $893.94(-3.35)$ & $908.71(-1.75)$ & $895.18(-3.21)$ \\
\hline Total water & 1030.86 & $1041.07(0.99)$ & $875.87(-15.03)$ & 1063.63 & 1003.94 & 1022.82 & 1014.60 \\
\hline yield & & & & $(3.17)$ & $(-2.61)$ & $(-0.77)$ & $(-1.57)$ \\
\hline Evaporation & 387.5 & $384.7(-0.72)$ & $386.8(-0.18)$ & $408.7(5.47)$ & $400.9(3.45)$ & $407.9(5.26)$ & $399.2(3.01)$ \\
\hline
\end{tabular}


Table 7. Average annual basin values as simulated by SWAT Model fed with climate data from RCM Ensemble average for two scenarios RCP 4.5 and RCP 8.5 : Note that figures in brackets are \% change

\begin{tabular}{|c|c|c|c|c|c|c|c|}
\hline \multirow[b]{3}{*}{ Units in $\mathrm{mm}$} & \multirow[b]{3}{*}{$\begin{array}{c}\text { Baseline } \\
(1971-2000)\end{array}$} & \multirow{2}{*}{\multicolumn{2}{|c|}{$\begin{array}{c}\text { Present century } \\
2011-2040\end{array}$}} & \multirow{2}{*}{\multicolumn{2}{|c|}{$\begin{array}{c}\text { Mid century } \\
\text { 2041-2070 }\end{array}$}} & \multirow{2}{*}{\multicolumn{2}{|c|}{$\begin{array}{c}\text { End century } \\
2071-2100\end{array}$}} \\
\hline & & & & & & & \\
\hline & & $\begin{array}{c}\text { RCP } 4.5 \\
\text { (\% change) }\end{array}$ & $\begin{array}{c}\text { RCP } 8.5 \\
\text { (\% change) }\end{array}$ & $\begin{array}{c}\text { RCP } 4.5 \\
\text { (\% change) }\end{array}$ & $\begin{array}{c}\text { RCP } 8.5 \\
\text { (\% change) }\end{array}$ & $\begin{array}{c}\text { RCP } 4.5 \\
\text { (\% change) }\end{array}$ & $\begin{array}{c}\mathrm{RCP} 8.5 \\
\text { (\% change) }\end{array}$ \\
\hline Precipitation & 1177.1 & $11192.97(5.34)$ & $1193.5(1.39)$ & $1188.15(0.93)$ & $1176.925(-0.01)$ & $1196.2(1.62)$ & $1200.275(1.96)$ \\
\hline Surface runoff & 8.8025 & $11.86(34.73)$ & $11.59(31.6)$ & $13.36(51.80)$ & $12.6(43.87)$ & $13.65(55.12)$ & $18.83(114.00)$ \\
\hline Groundwater & 715.51 & $724.89(1.31)$ & $678.67(-5.14)$ & $717.64(0.29)$ & $686.89(-3.99)$ & $724.96(1.32)$ & $700.23(-2.13)$ \\
\hline Total water yield & 797.7475 & 811.21(1.68) & $759.05(-4.85)$ & $809.67(1.49)$ & $771.115(-3.33)$ & $819.16(2.68)$ & $791.98(-0.72)$ \\
\hline Evaporation & 355.425 & $360.875(1.53)$ & $359.225(1.06)$ & $376.5(5.92)$ & $381.05(7.20)$ & $381.4(7.30)$ & $433.925(22.08)$ \\
\hline
\end{tabular}

\section{Discussion}

The uncertainties in the previous study done by Wambura (2015) on the impacts of climate change on stream flows using climate change simulations derived by GCMs offer a room for more research to be done on the hydrological responses due to climate change. In this study, we have used high resolution climate information from four Regional Climate Models (RCMs) driven by three General Circulation Models (GCMs) and Soil and water Assessment tool embedded in Arc GIS to simulate stream flows over the Mbarali River sub catchment during historical, and future periods under two emission scenarios (RCP 4.5 and RCP 8.5).

This work aimed at assessing, how climate change will affect hydrological characteristics of the Mbarali River Sub catchment in the Upper Great Ruaha sub basin of Rufiji Basin. This River sub-catchment is an agricultural watershed which produces food and cash crop in Tanzania country (Milder et al., 2013). As a result, much assessment on how climate change will impact future water availability within Mbarali River sub catchment is of great important. The study revealed that temperatures are projected to increase throughout the sub-catchment. Different RCM-GCM combinations project increase in temperatures differently. Yet, the ensemble average of the RCMs approves that the sub-catchment will have high change in temperatures during the end century under RCP 8.5.

The ensemble average project that minimum temperature will increase by $14 \%\left(1.9^{\circ} \mathrm{C}\right)$ under RCP 8.5 and maximum temperature will increase by $7.68 \%\left(1.8^{\circ} \mathrm{C}\right)$ under the same scenario RCP 8.5 . These increases in temperature will raise the evaporation within the sub-catchment and hence contributing to the decrease in the stream flows, particularly in the warmer low altitude areas.

The ensemble average of the River Sub-catchment value and climate variable are presented on Table 7. The hydrological model SWAT simulates differently when two different RCMs are forced by similar GCM. The differences are related with the design of the RCMs themselves. For the case, RACMO22T and HIRHAM5 enforced by similar GCM(ICHEC-EARTH) simulate different amount of stream flows, surface runoff, water yield and ground water yield in historical climate (1971-2000), present climate (20110-2040), mid (2041-2070) and end (2071-2100) centuries.

Likewise, different amount of water balance components are simulated when are forced by the same RCM derived by different GCMs. For instance, SWAT simulates different amount of stream flows and surface runoff, and water yields even when is forced by the same RCM (RCA4) driven by different GCMs (CNRM, and MPI). In this case, the difference comes from the variations of formulation of the driving GCMs. The annual rainfall projections show a significant increase in the averages of the three projected periods relative to the baseline period for both RCP4.5 and RCP8.5 scenarios. These projections converge with the projections of temperatures in the River sub catchment. Moreover, as with the temperatures, the increase under the RCP8.5 scenario is higher than that obtained under the RCP4.5 scenario.

The projected decrease of the stream flows in the Mbarali River Sub-catchment may result in the decrease in the amount of water availability. This may have negative impacts on the aquatic biota, water quality and agriculture. The projected increase in the surface run-off may cause serious environmental problems such as soil erosion and floods.

It is important to note that the uncertainties related to the current assessment, which is based on the downscaling of the high resolution regional climate model driven by three members of the GCM (ICHEC, MPI and CNRM) simulations of the RCPs emission scenario were considered. The included simulations are the most and the least climate sensitivity member of the GCM runs, and it is believed that more environmentally concerned and more 
business-as-usual scenarios have been somewhat considered in these simulations. As a result, some insights in the possible future changes to the river flow under the future climate change have been provided in this work. Despite uncertainties of the projections, the results showed some level of agreement with other works, and therefore they contain some level of confidence to the hydrological impacts in the Mbarali River Sub-catchment, which makes the information a useful guidance for local adaptation measures.

\section{Conclusion}

In this study we assessed the impact of climate change on stream flows and hydrological condition of the Mbarali River sub catchment which is located $1530 \mathrm{~km}^{2}$ in the Upper Great Ruaha of the Rufiji Basin, Tanzania. SWAT, a distributed hydrological model was employed to simulate the stream flows and hydrological condition of the River sub-catchment. The climate variable graded from the cordex project for the present period (1971-200) was compared with the three future periods (2011-2040, 2041-270 and 2071-2100) with their respective RCP 4.5 and RCP8.5 as input into a distributed hydrological model, SWAT. Calibration and validation of SWAT model show that the tool can be a reliable for hydrology cycle simulation in Mbarali River sub-catchment.

The future annual rainfall and temperature are projected to increase while the annual stream flows are projected to decrease. A significant decrease of projected monthly stream flow during the year might cause drying up of the Mbarali river and hence decreasing the environmental condition of the aquatic organism in the future. Additionally, the decreases in monthly stream flow during March and April would lead to water shortage problems that have been occurring in previous years. The climate of the study area is becoming hotter in both wet and dry seasons. To couple with all this condition, the basin water users and other stakeholder should apply integrated water resources management at all levels.

\section{Acknowledgments}

This work was carried out under the Future Climate for Africa UMFULA project, with financial support from the UK Natural Environment Research Council (NERC), grant ref. No: NE/M020037/1, and the UK Government's Department for International Development (DfID). I would like to thank the CORDEX Africa for providing model data used in this study. The Regional climate model simulations were performed with the Grid Analysis and Display System (GrADS) an interactive desktop tool that is used for easy access, manipulation, and visualization of earth science data.

\section{References}

Abbaspour, K. C., Faramarzi, M., Ghasemi, S. S., \& Yang, H. (2009). Assessing the impact of climate change on water resources in Iran. Water Resource Research, 45, 1-16.

Arnold, J. G., Srinivasan, R., Muttiah, R. S., \& Williams, J. R. (1998). Largearea hydrologic modeling and assessment model development. Journal of American Water Resource Association, 34(1), 73-89.

Climate System Analysis Group. (2010). Technical Overview: Regional climate change. Environmental and Geographical Sciences University of Cape Town South Africa. Retrieved from www.csag.uct.ac.za

IPCC. (2014). Working Group II Fourth Assessment Report. Climate Change Impacts, Adaptation and Vulnerability. Intergovernmental Panel on Climate Change, Cambrige., USA. 987pp.

Kashaigili, J. J. (2008). Impacts of land-use and land-cover changes on flow regimes of the Usangu wetland and the Great Ruaha River, Tanzania. Physics and Chemistry of the Earth, 33, 640-647.

Kossa, R. M. R. (2007). Water availability and use dynamics and the sustainability of water resources management in the great Ruaha river catchment in Tanzania. Thesis for Award of PhD Degree at Sokoine University of Agriculture, Morogoro, Tanzania, 325pp.

Luhunga, P. (2017). Assessment of the Impacts of climate change on maize production in the southern and western highlands sub-agro ecological Zones of Tanzania:Frontiers Environment Science, 5(51), 1-17.

Masson, D., \& Knutti, R. (2011). Spatial-scale dependence of climate model performance in the CMIP3 ensemble. Journal of Climate, 24, 2680-2692.

Milder, J. C., Buck, L. E., Hart, A. K., Scherr, S. J., \& Shames, S. A. (2013). A Framework for Agriculture Green Growth. Southern Agricultural Growth Corridor of Tanzania, Dar es Salaam, Tanzania. 88pp.

Mueller, B., \& Seneviratne, S. I. (2014). Systematic land climate and evapotranspiration biases in CMIP5 simulations. Geophysical Research Letters, 41(1), 128-134. 
Mutayoba, E., \& Kashaigili, J. J. (2017). Evaluation for the Performance of the CORDEX Regional Climate Models in Simulating Rainfall Characteristics over Mbarali River Catchment in the Rufiji Basin, Tanzania. Journal of Geoscience and Environment Protection, 5(4), 10-42.

Mwandosya, M. J., Nyenzi, B. S., \& Luhanga, M. L. (1998). The Assessment of Vulnerability and Adaptation to Climate Change Impacts in Tanzania. Centre for Energy, Environment, Science and Technology, Dar es Salaam. 235pp.

Nikulin, G., Jones, C., Giorgi, F., Asrar, G., Büchner, M., Cerezo- Mota, R., ... Sushama, L. (2012). Precipitation climatology in an ensemble of CORDEX-Africa regional climate simulations. Journal of Clime Change, 3, 6057-6078.

Piani, C., Weedon, G. P., Best, M., Gomes, S. M., Viterbo, P., Hagemann, S., \& Haerter, J. O. (2010). Statistical bias correction of global simulated daily precipitation and temperature for the application of hydrological models. Journal of Hydrology, 395(4), 199-215.

Ramirez-Villegas, J., \& Challinor, A. (2012). Assessing relevant climate data for agricultural applications. Agricultural and Forest Meteorology, 161, 26-45.

Stisen, S., \& Tumbo, M. H. (2015). Interpolation of rain gauge data for hydrological modelling in data sparse regions using pattern information from satellite data. Hydrological Sciences Journal, 60, 1911-1926.

Wambura, F. J. (2014). Stream flow response to skilled and non-linear bias corrected GCM precipitation change in the Wami River Sub-basin, Tanzania: British Journal of EnvironmentClime Change, 4(4), 389-408.

Zappa, M. (2002). Multiple-response verification of a distributed hydrological model at different spatial scales. Thesis for Award of PhD Degree at Swiss Federal Institute of Technology, Zurich, Switzerland, 168pp.

Zhang, G. (2006). Analysis on potential effects of global climate change on natural runoff in the Yellow River Basin. Geographical Research, 25(2), 268-275.

\section{Copyrights}

Copyright for this article is retained by the author(s), with first publication rights granted to the journal.

This is an open-access article distributed under the terms and conditions of the Creative Commons Attribution license (http://creativecommons.org/licenses/by/4.0/). 